\title{
Радиофикация Республики Бурятия в 1920 гг.
}

Баярма Шагдарова

Ольга Тихонова

В статье представлены результаты историографического исследования начального этапа становления отечественного радиовещания на примере Бурятии. В аспекте заявленной темы 1920 гг. в науке пока мало изучены, что связано с ограниченной эмпирической базой. Сохранившиеся в республиканских архивах документы, а также материалы местной прессы того времени позволили восстановить в хронологической последовательности процесс радиофикации данного региона, выявить роль в нем движения радиолюбителей и Общества друзей радио.

Ключевые слова: радиовещание, Бурятия, радиофикация республики, Общество друзей радио, движение радиолюбителей.

DOI: 10.30547/mediaalmanah.6.2020.7382

(c) Шагдарова Баярма Баторовна

кандидат исторических наук, доцент кафедры журналистики и рекламы Института филологии, иностранных языков и массовых коммуникаций Бурятского государственного университета имени Доржи Банзарова

(г. Улан-Удэ, Россия), bayarma70@mail.ru

(C) Тихонова Ольга Владимировна

кандидат филологических наук, доцент кафедры телевидения и радиовещания

факультета журналистики

МГУ имени М.В. Ломоносова

(г. Москва, Россия), tihonovao@list.ru

\section{Введение}

Радиовещание с момента зарождения в нашей стране выполняло важные коммуникационные функции, считалось действенным рычагом советской власти в деле идеологического влияния на слушателей, но главное - благоприятствовало повышению их образовательного и культурного уровня.

Внимание к новому виду журналистики было пристальным как в 1920 гг. (со стороны так называемой радиопрессы), так и позднее, в послевоенное время, что отражалось в научных публикациях и изданиях. Тема отечественного центрального радио привлекала внимание многих исследователей (Воробьев, Казаков, Мельников, 1972; Глейзер, 1965; Горяева, 2000; Гуревич, Ружников, 1976; Ружников, 1987; Тихонова, 2017 и др.). При этом история радиовещания регионов, и особенно его начального экспериментального этапа, до сих пор остается малоизученной в науке о радиожурналистике, хотя следует отметить, что интерес к данной тематике актуализировался (Быкова, 2008; Пряженникова, 2011; Симонова, 2019; Шуркина, 2002 и др.). В издании факультета журналистики МГУ имени М.В. Ломоносова «Радио: начало истории. К 120 -летию» отдельный раздел посвящен теме становления и развития регионального и национального 
радиовещания в СССР (Даутова, 2017; Ковтун, Тихонова, 2017; Круглова, 2017; Овсепян, 2017; Тихонова, 2017; Цуканова, 2017).

Вопрос радиофикации Бурятии в монографии «Журналистика Бурятии в первой половине XX века» (Шагдарова, 2013) только обозначен, что позволяет говорить о недостаточной научной разработанности данной темы. В связи с этим авторы представленной статьи на основе архивного материала, газетных публикаций 1920 гг. предпринимают попытку изучить важный процесс в истории отечественного республиканского радио.

Исторический контекст становления и развития радиовещания в Бурятии в начальный период обусловлен необходимостью его продвижения в национальные районы страны, где население долгое время находилось практически в информационной изоляции, и широкого использования его в агитационно-массовой и культурно-просветительной работе.

Благодаря процессу планомерного развития сети радиовещания, постепенно набиравшему темпы на фоне созданной радиотехнической промышленности, Москва получила возможность поддерживать необходимую регулярную связь с отдаленными областями и республиками. Исключительное значение радио имело для малограмотных жителей Советской России и национальных окраин: в стране, где «основная масса населения только-только училась читать, тот факт, что радио обладало целым комплексом возможностей звукового воспроизведения жизни, имел огромное значение» (История советской радиожурналистики, 1991: 5).

Стоит подчеркнуть, что «уже в первые месяцы советской власти были заложены основы государственного руководства и делом радиотехнического строительства, и использованием радиотелеграфа как средства опосредованного информирования и просвещения масс» (Тихонова, 2017: 37). Процесс превращения радио из исключительно технического способа оперативной связи в канал массовой доставки новостей и средство пропаганды способствовал укреплению руководства центром страны отдаленными окраинами.

Территория государства была разделена на Округа связи, которые непосредственно подчинялись Народному комиссариату почт и телеграфов (НКПиТ). Появилась возможность сообщения с теми районами Сибири, где природные условия позволяли поддерживать связь только радио. В 1922-1923 гг. Правительством СССР был намечен план радиостроительства, по которому в 22 населенных пунктах сибирского региона предусматривалось ввести в строй радиостанции для непосредственной связи со столицей. К октябрю 1922 г. там насчитывались одна приемно-передающая радиостанция и 17 приемных радиостанций, пять из них действовали в Иркутской, Якутской и Енисейской губерниях Восточно-Сибирского округа связи (Шестопалова, 2008: 50).

\section{Радиофикация в Монголо-Бурятской автономной области}

В отличие от ряда других сибирских округов в Бурят-Монголии е было приемных и передающих технических устройств. Развернувшееся строительство молодой Бурят-Монгольской Автономной Советской Социалистической Республики (БМАССР), образованной решением Президиума ВЦИК РСФСР от 30 мая 1923 г. на основе объединения автономных областей Сибири и Дальнего Востока с центром в г. Верхнеудинске (с 1934 г. Улан-Удэ), сыграло решающую роль в становлении местной сети радиовещания. Первые радиосообщения из Москвы и ряда других городов СССР стали принимать в 1923 г., когда радиолюбители вручную собрали четыре радиоприемника. Открывшие в Бурятии «эру» радио энтузиасты-конструкторы и в дальнейшем имели особое значение в области освоения эфира и создания республиканской радиосети. Их усилия 
и опыт внесли неоценимый вклад в решение радиотехнических проблем, обусловленных отсутствием подготовленной материальной базы, нехваткой финансовых средств и др.

Активизация движения радиолюбителей в Бурятии и в целом в стране была вызвана принятием в 1924 г. Постановления СНК СССР «О частных приемных радиостанциях", на основании которого всем предоставлялось право проводить радиоэксперименты. Данный документ более известен в истории отечественного радиовещания как Закон о свободе эфира, после принятия которого вскоре появился термин «радиовещание». Буквально незадолго до этого «...на страницах журнала "Техника связи" шла оживленная дискуссия, где слово "широковещание" (которым пользовались для обозначения радиовещания) предлагали заменить одним из следующих: "звукомет”, "искромет", "радиомет" и др.» (Круглова, 2017: 66). К этому же периоду относится возникновение Общества радиолюбителей РСФСР, переименованного спустя полгода в Общество друзей радио (ОДР).

25 марта 1925 г. в Верхнеудинске было образовано Общество друзей радио Бурятии, объединившее местных энтузиастов-радиолюбителей, которые со всей ответственностью начали вести радиостроительство в республике, что было документально зафиксировано в Уставе ОДР БМАССР, включившем 57 параграфов. Так, члены общества имели «право строить и устанавливать передающие и приемные радиостанции и пользоваться ими, а также государственными и иными станциями для регулярной передачи и приема заседаний руководящих органов СССР, докладов, лекций, громкоговорящих реклам» (Шагдарова, 2013: 45) и приравнивались к государственным рабочим и служащим. Устав ОДР вступил в силу в 1926 г. после утверждения наркомом внутренних дел Бурятии Варгановым², который в своем заключении определил, что «названное общество не преследует цели извлечения прибыли» (Шагдарова, 2013: 46). В числе учредителей Общества радиолюбителей и членов его президиума значились председатель ЦИК и СНК Бурятии М.Н. Ербанов, управляющий делами ЦИК и СНК Бурятии И.Ф. Головачев, а также заведующий технической частью Верхнеудинской почтово-телеграфной конторы С.Д. Мельников.

Становление и развитие радиовещания в Бурят-Монгольской Автономной Советской Социалистической Республике отставало от центральных регионов страны, где уже начиная с 1922 г. в эфире звучали сообщения в форме первых передач отечественного радиовещания - радиогазет. В 1927 г. руководство республики при финансовой поддержке различных организаций, прежде всего Бурятского республиканского союза потребительских обществ (Буркоопсоюза), и активном участии ОДР приобрело первую заводскую радиоустановку - в пределах города были переданы первые радиосигналы. Следует отметить, что участие потребительской кооперации в процессе радиофикации наблюдалось не только в рассматриваемом регионе, но и в других национальных республиках и областях СССР.

Запуск радиоустановки состоялся 25 марта 1927 г. во время республиканского съезда Советов. Историческое значение этого события связано с началом регулярной передачи в эфир радиогазет в Верхнеудинске. Принцип вещания того времени характеризовался передачей сообщений при помощи «форпостных» телефонов. Рупоры-громкоговорители были установлены на здании Совнаркома на главной улице Ленина и железнодорожного клуба. Благодаря успешной работе радистов слышимость и качество звучания отличались достаточно хорошим уровнем. Осенью 1928 г. дополнительный комплект усилительного прибора помог передать радиосообщения по воздушным проводам из Межсоюзного дома самодеятельного творчества, 
Таблица. «Количественные характеристики публикаций по теме «радио» на страницах газеты «Бурят-Монгольская правда» в 1926-1929 гг.

\begin{tabular}{|l|c|c|c|c|c|}
\hline \multicolumn{1}{|c|}{ Характеристики } & $\mathbf{1 9 2 6}$ r. & $\mathbf{1 9 2 7}$ г. & $\mathbf{1 9 2 8}$ г. & $\mathbf{1 9 2 9}$ г. & Всего \\
\hline Количество публикаций & 4 & 12 & 6 & 2 & 24 \\
\hline Тема радиофикации & 2 & 9 & 3 & 1 & 15 \\
\hline Тема ОДР & 2 & 3 & 3 & 1 & 9 \\
\hline Жанр заметки & 3 & 11 & 4 & 2 & 20 \\
\hline Жанр статьи & 1 & 1 & 2 & - & 4 \\
\hline $\begin{array}{l}\text { Автор - корреспондент } \\
\text { газеты }\end{array}$ & - & - & 3 & - & 3 \\
\hline Автор - член ОДР & 4 & 12 & 3 & 2 & 21 \\
\hline
\end{tabular}

располагавшегося в доме 46 на улице Ленина, что ознаменовало факт зарождения в БМАССР проводного радиовещания. Это был успех, достигнутый радиолюбителями благодаря их годовому радиоэксперименту (Шагдарова, 2013: 47).

\section{Движение радиолюбителей и Общество друзей радио}

Результаты развития сферы радиостроительства связаны с участием радиолюбителей, обсуждавших вопросы радиофикации даже на страницах местной печати (см. табл.).

Как показывают результаты количественного анализа выборки тематических материалов архивных подшивок (19261929 гг.) ведущей республиканской общественно-политической газеты «Бурят-Монгольская правда», сохранившихся в Государственном архиве Республики Бурятия (ГАРБ), публикаций, посвященных радио как новой для того времени области науки и техники, не так много. Пик публикационной активности на тему радиофикации объяснимо пришелся на 1927 г., когда в Верхнеудинске была введена в строй радиоустановка и его жители впервые услышали голос диктора из уличных репродукторов. О событиях сообщалось преимущественно в информационных заметках. Хотя здесь необходимо отметить, что даже в таком чрезвычайно лаконичном жанре печатной журналистики нами зафиксированы аналитические элементы текстов, что предположительно может быть связано с преобладающим авторством членов ОДР.

Одной из первых публикаций Общества друзей радио в данном издании стала в 1926 г. заметка «В общественных организациях: друзья радио в Бурятии» (без указания автора) о прошедшей встрече членов Бурят-Монгольского отдела ОДР: «На собрании присутствовало до 40 человек - члены учреждений и представители организаций. Собранием утвержден устав и избран совет»4.

Радиолюбитель Абрамсон из Верхнеудинска (без указания имени или инициалов) в заметке «Простой детекторный радиоприемник и его устройство" доходчиво проводит инструктаж по пользованию приемником: «...приключаем антенну в землю к соответствующим клеммам и вставляем детектор и телефон. Детектор мы советуем не делать самим, а купить готовый в магазине треста завода слабых токов или в Радиопередаче (Москва) за 1 руб. 50 коп. Телефонная трубка может быть не только специальная, но и обыкновенного типа»5. Другой радиолюбитель М. Зинков высказывает серьезную озабоченность по поводу степени эффективности процесса радиофикации: «Конечно, ближе к центру места богаче и культурней БМАССР, но все же, когда читаешь: “В Тульской губернии 
установлено свыше 1000 радиоприемников", невольно встает вопрос: хорошо, мы бедны, но хотелось бы и нам поставить 100, 10,1 , наконец, радиоприемник». Более того, автор размышляет и предлагает пути решения проблемы, насущной для отдаленного от центра страны региона: «Очевидно, культурные и заинтересованные организации Бурполитпросвет, Бурпрофсовет, Буркоопсоюз должны как-то решить вопрос о материальной базе. Сразу больших сумм не потребуется, т.к. на первых порах нужно было бы установить лишь только городскую передаточную станцию, откуда концерты и доклады передавались бы в приемники громкоговорителя» ${ }^{6}$.

Такие печатные материалы по теме радиостроительства в местной прессе оказывали заметное влияние на популяризацию радио в период становления этого вида вещания. Сами радиолюбители с неутомимым энтузиазмом проводили технические эксперименты с целью достижения уверенного приема сигналов из других городов, в первую очередь из столицы. Об успехах, имевших особое значение в истории отечественного радио, кратко отчитались, к примеру, в заметке «Алло! Алло! Алло! Говорит Москва»: «Радиостудией гор. В.Удинска произведены первые опыты усиления приема радиопередач из Новосибирска. Опыт дал положительные результаты. 17 ноября были проведены новые опыты приема радиопередач иногородних станций и в 1 час 9 мин. ночи с 17 на 18 ноября В.Удинская радиостудия услышала оперу на русском языке. Радиостудия продолжает свои интересные наблюдения и дождалась... прилетели слова: Алло... алло... алло... говорит Москва. В.Удинский громкоговоритель передавал речи, мотив пения... но пока невнятно. Наша радиостудия надеется тесно связать сердце СССР - Москву с далекой окраиной - Бурятией»7.

В первый год функционирования местного ОДР произошло немало других событий в сфере радиостроительства и организации вещания, что в обязательном порядке отражалось на страницах периодической печати ${ }^{8}$. В публикациях говорилось не только об инженерных достижениях, но и трудностях в работе: к примеру, о случаях простоев громкоговорителей или нарушениях графика выхода передач. Автор МИХ (по-видимому, член ОДР) в заметке «И есть оно, и нет его...» сообщает подробности вопиющего халатного отношения к делу: «Вот уже вторая неделя, как репродукторы молчат. Никакой системы, плана в радиопередаче нет. И даже больше: радиопередачи как таковой вообще нет. А позавчера, в воскресенье, было еще хуже: просто кто-то что-то кричал в микрофон. О чем? Почему? Неизвестно». Таким риторически-сатирическим вопросом предпринимается попытка дать аргументированный ответ не просто радиолюбителя, а человека активной гражданской позиции относительно возникшей ситуации: «Такое использование приемника - никуда не годится. Так мы никого не вовлечем в ОДР, так мы отучим публику от радио, и никто не будет слушать даже тогда, когда мы начнем принимать иногородние станции. Необходимы срочные меры. Организацию радиопередач нужно передать в твердые руки, привлечь к участию в радиопередачах лучшие силы города, ассигновав в случае надобности 200-250 руб. гонорар некоторым из радиолюбителей. Радиопередачи должны проводиться регулярно с объявлением о них заранее в газете»9.

Общество друзей радио Бурятии стало инициатором в рассматриваемой нами республиканской газете ряда статей, приуроченных к дате основания ОДР республики ${ }^{10}$.Так, 25 марта 1928 г. на третьей полосе «Бурят-Монгольской правды» была размещена публикация о проблемах и достижениях деятельности Общества: «Отсутствие элементарных понятий о радиотехнике среди коренного населения Бурят-Монголии, отсутствие радиотехнической базы для развертывания практической 
опытно-показательной работы и, наконец, отсутствие радиоспециалистов»; «Провело курсы, подготовило 27 начинающих радиолюбителей, организовало радиотехническую и коротковолновую секции, организовало 14 ячеек с 500 членами ОДР и, наконец, устроило за свой счет установку для передачи местных радиогазет и радиоконцертов, а также приемную опытную радиостанцию с усилителем и принимает по радио для небольшой аудитории Москву, Новосибирск, Иркутск, Харбин, Шанхай и много других станций. На приобретение радиоаппаратуры и ее содержание истрачено за два года 4000 р.»11. Руководством ОДР также отмечалось, что волновые сигналы местных радиопередач и трансляций из других городов доходят до близлежащих к Верхнеудинску сел, возрос интерес граждан к радиослушанию и радиотехнике.

Другой печатный материал газеты «Бурят-Монгольская правда» содержит отчетную информацию о состоявшейся в Совете народных комиссаров БМАССР встрече членов Общества друзей радио с руководством республики, некоторые интересные для темы исследования статистические данные: «Имеется опытная радиоприемная станция с громкоговорящими установками, стоющая до 4 тыс. руб. Будет организован фонд в 1200 руб. на постройку в Верхнеудинске широковещательной станции с охватывающей всю территорию Бурятии и часть Монголии. Намечены мероприятия по изысканию этих средств»12.

В этом же № 7 за 1928 г. читатели издания узнали о строительстве в Иркутске (и открытии к 1 октября) мощностью в 10 кВт широковещательной радиостанции, которая «будет иметь радиус действия в 1000 верст и в Бурятии можно будет принимать передачу на простой (детекторный) приемник»13.

Радиолюбители республиканского центра - Верхнеудинска - оказывали посильную организационно-техническую помощь членам ОДР в районах и также аймаках, объединявших несколько сельсоветов с преимущественно бурятским населением. Ряд первоочередных мероприятий заявлен в статье с громким названием «Радио на службе у рабочих и крестьян». В ней предлагалось «создать более дешевый и простой громкоговорящий прибор для рабочих клубов и изб-читален; выпустить набор отдельных частей для самостоятельной сборки радиоприемников, а также самый дешевый детекторный приемник для деревни. Далее - нужно не только наготовить прибор и доставить на место: нужно научить любителей, как с этими приборами обращаться...». Кроме того, почти лозунгами, высокопарными фразами доносится до читателей суть проводимой радиофикации, рисуются ближайшие перспективы: «ОДР обеспечит развитие радиопромышленности, создает целые полки работников, знающих радиодело, для того, чтобы бросить их по линии, указанной коммунистической партией, на связь города с деревней, на просветительскую работу и, если придется, на борьбу с классовым врагом»14.

Появление кустарныхприемных установок в селах становилось событием нерядового масштаба. В репортаже «Бурят-Монгольской правды» образно освещался воскресник, организованный радиолюбителями в отдаленном селе Кырен Тункинского района: «В 9 часов утра в воскресенье стали дружно собираться служащие всех учреждений во двор комендатуры ОГПу15 для подъема мачты радиоустановки. Посредине двора, как желтый труп, лежит 15-саженная махина. Вокруг толпятся возбужденные радостные люди. Слышится говор на разных наречиях <...> Шумит кузнечный горн, разогревая скрепы, звенят щипцы, колышутся лестницы и кажутся живыми, исполняющими свое большое дело. Наконец, народ расставлен по местам, к концам веревок, приготовлены багры, проволока <...> Еще одно дружное усилие и, дрогнув в последний раз гибким стволом, мачта встала на место, укрепленная протянувшимися во все 
стороны проволоками, приветствуя кыренцев взмахом красного флажка на вершине. И там, где только два года назад сияла медными украшениями крыша кумирни, теперь высится радиомачта, один из путей к социализму. Пошли ставить другую мачту во дворе п/т. конторы, а вслед из-за оврага, размытого р. Кыренкой будто с досадой, рвались печальные звуки медных труб из храма Сохиши дацана и ритмичные гулкие удары барабана. Через день кыренцы будут слушать Москву»16.

В республиканской газете северобайкальцы вскоре отрапортовали об установке первого приемника, что явилось важным событием в регионе: «БурЦИКом получена от Северо-Байкальского туземного РИКа приветственная телеграмма по случаю открытия в Северо-Байкальском туземном районе первого радиоприемника, установленного Северо-Байкальским интегральным кооперативом. Приветствия переданы от собрания 150 человек - участников радиоприемки»17.

В конце 1928 г. на третьей полосе общественно-политической газеты «БурятМонгольская правда» появилась рубрика «На радиофронте», которую открывала заметка о начале проектирования членами ОДР радиопередатчика мощностью до 20 Вт. Автор под псевдонимом Анод обращался со страницы издания к жителям г. Верхнеудинска с просьбой внести посильный взнос на создание радиоустановки ${ }^{18}$. О результатах этой деятельности сообщалось в № 54 издания в заметке радиолюбителя Ф.П. Танганова «Устроили радио»19. Из другой заметки «Курсы радиолюбителей», на этот раз без указания автора, читатель узнает об инициативе Президиума ОДР БМАССР, связанной с вовлечением граждан в ряды радиолюбителей. Цель специально созданных курсов заключалась в том, чтобы «подготовить кадры технически грамотных руководов, кружков радиолюбителей, могущих в то же время самостоятельно сделать детекторный приемник и устанавливать и обслуживать сложные многоламповые радиоприемники. Руководству будут крайне необходимы к моменту открытия иркутской мощной радиостанции и нашего местного радиопередатчика. Курсы двухмесячные, рассчитаны на 50 человек. На курсы уже записалось 32 комсомольца, 9 учащихся»20.

В 1929 г. Общество друзей радио Бурятии настолько заметно сократило свое участие в пропаганде радиостроительства и радиовещания в местной прессе, что даже такое важное для радиолюбителей событие, как очередная годовщина образования широко известной в республике общественной организации, никак не освещалось на страницах печати. В целом близился к завершению экспериментальный период радио Бурятии, история которого была тесно связана с активной работой радиолюбителей, чьи усилия по популяризации и продвижению радио в массы заложили прочные основы радиотехнического дела и радиовещания в республике.

\section{Заключение}

Важнейшим результатом совместной работы Общества друзей радио Бурятии и местной власти явилась инициатива правительства БМАССР по выработке плана радиофикации республики в 1928-1929 гг. на сумму 25000 руб.21 В вышедшем официальном документе также поручалось ОДР провести вещевую лотерею на сумму 40000 руб., собранные средства направить на приобретение заводской широковещательной радиопередаточной установки с целью разворачивания в республике проводного вещания и улучшения качества трансляции московских радиопередач.

Итак, широко проводимая в стране радиофикация расширяла охват аудитории слушателей в отдаленных районах, в том числе и в рассматриваемом в данной статье регионе, где этап становления регулярного вещания был связан с созданием при СНК Бурятии комитета по радиофикации 
и радиовещанию. При этом новый канал массового информирования и пропаганды формировался все же довольно медленно, процесс радиофикации районов, аймаков, промышленныхпредприятий и учреждений по темпам отставал от экономически более развитых краев и областей СССР. Введенная в строй широковещательная станция PB-63, слабая по мощности, требовала технического оснащения, сбои в ее функционировании отрицательно влияли на качество эфира республиканского вещания.
Только уже к середине 1930 гг. партийное руководство БМАССР и Совет народных комиссаров приняли ряд мер для разрешения непростой ситуации в области радиофикации и радиовещания. Специальным постановлением Бюро Окружного комитета ВКП(б) были запланированы как закупка новых эфирных радиоустановок, открытие тринадцати радиоузлов, так и упрочение материально-технической базы местного радиокомитета, организация новых площадей для аппаратной и радиостудии.

\section{Примечания}

1 Национальное буферное государство бурят времен гражданской войны, существовавшее в период 1917-1920 гг. и образованное по решению I Всебурятского съезда 25 апреля 1917 г.

2 Инициалы персоналий в республиканских архивах не сохранились.

3 В приводимых в данной статье названиях и цитируемых фрагментах газетных публикаций сохранены орфография, пунктуация, написание (сокращение) архивных текстов в варианте оригинала.

4 В общественных организациях: друзья радио в Бурятии // Бурят-Монгольская правда. 1926. № 68. Март, 28. С. 4.

5 Абрамсон. Простой детекторный радиоприемник и его устройство // Там же. 1926. № 49. Март, 14. С. 3.

6 Зинков М. Чем мы хуже? // Там же. 1926. № 49. Март, 14. С. 3.

7 «Алло! Алло! Алло! Говорит Москва» // Там же. 1927. № 264. Ноябрь, 22. С. 6.

8 Копылов. Покупка радиоприемника // Там же. 1927. № 22. Янв., 30. С. 6; Слышим Новосибирск // Там же. 1927. № 27. Февр., 2. С. 4; Большаков. В уголке будет радио // Там же. 1927. № 60. Март, 20. С. 4; Слушаем съезд по радио // Там же. 1927. № 64. Март, 25. С. 4; Как устанавливается радиоустановка // Там же. 1927. № 66. Март, 27. С. 4; Чувырло. Всем! Всем! Всем! // Там же. 1927. № 66. Март, 27. С. 4 и т.д.

9 МИХ. И есть оно, и нет его... // Там же. 1927. № 79. Апр., 12. С. 4.

10 Фактически Общество друзей радио БМАССР было организовано 25 марта 1925 г., но его устав официально утвержден только в 1926 г.

11 К двухлетию Общества друзей радио // Бурят-Монгольская правда. 1928. № 69. Март, 25. С. 5.

12 Первая конференция «Общества друзей радио» // Там же. 1928. № 77. Апр., 4. С. 4.

13 В Иркутске строится радиостанция // Там же. 1928. № 77. Апр., 4. С. 4.

14 Радио на службе у рабочих и крестьян // Там же. 1926. № 71. Апр., 1. С. 4.

15 Объединенное государственное политическое управление.

16 Подняли мачты радиоустановки // Бурят-Монгольская правда. 1928. № 228. Окт., 3. С. 3. 
17 Первая радиоустановка в Северо-Байкалье // Там же. 1928. № 260. Ноябрь, 11. С. 3.

18 Анод. На радиофронте // Там же. 1928. № 299. Дек., 28. С. 3.

19 Танганов Ф.П. Устроили радио // Там же. 1929. № 54. Март, 7. С. 1.

20 Курсы радиолюбителей // Там же. 1929. № 71. Март, 29. С. 4.

21 К двухлетию Общества друзей радио // Там же. 1928. № 69. Март, 25. С. 5.

\section{Библиография}

Быкова О.В. Зарождение и становление радиовещания в Центральном Черноземье: на примере Белгородчины // Науч. ведомости БелГУ. Сер.: История. Политология. Экономика. 2008. № 5 (45). С. 129-135.

Воробьев А.И., Казаков Г.А., Мельников А.И. Очерки истории советского радиовещания и телевидения. Ч. І: 1917-1941. М.: Мысль, 1972.

Глейзер М.С. Радио и телевидение в СССР. 1917-1963. М.: Гос. комитет Совета министров СССР по радиовещанию и телевидению, 1965.

Горяева Т.М. Радио России. Политический контроль советского радиовещания в 1920-1930-х годах. Документированная история. М.: РОССПЭН, 2000.

Гуревич П.С., Ружников В.Н. Советское радиовещание: страницы истории. М.: Искусство, 1976.

Даутова Р.В. Становление и развитие радио в Татарии в 1920-1930 годы // Радио: начало истории. К 120-летию: сб. науч. ст. М.: Фак. журн. МГУ, 2017. С. 167-176.

История советской радиожурналистики, 1917-1945: Документы, тексты, воспоминания / сост. Т.М. Горяева. М.: Изд-во Моск. ун-та, 1991.

Ковтун В.Г., Тихонова О.В. Как это было. Радиофикация и радиовещание в Ленинграде и области (1926-1928 гг.) // Радио: начало истории. К 120-летию: сб. науч. ст. М.: Фак. журн. МГУ, 2017. С. 115-139.

Круглова Л.А. О зарождении радиовещания: документы, цифры, даты (1914-1927) // Радио: начало истории. К 120-летию: сб. науч. ст. М.: Фак. журн. МГУ, 2017. С. 50-70.

Овсепян М.М. Республиканское радио Армении: этап становления // Радио: начало истории. К 120-летию: сб. науч. ст. М.: Фак. журн. МГУ, 2017. С. 156-166.

Пряженникова М.В. Становление и развитие радиофикации на территории Восточного Забайкалья (1920-30-е гг.) // Гуманитарный вектор. 2011. № 3 (27). С. 100-104.

Ружников В.Н. Так начиналось: историко-теоретический очерк советского радиовещания, 1917-1928. М.: Искусство, 1987.

Симонова И.Н. Радиовещание в Пензенской области (1920-1930-е гг.) // Изв. высш. учеб. заведений. Северо-Кавказский регион. Сер.: Общественные науки. 2019. № 2. С. 94-97.

Тихонова О.В. Радиограммы и радиовестники в Советской России: значение радиотелеграфа // Радио: начало истории. К 120-летию: сб. науч. ст. М.: Фак. журн. МГУ, 2017. С. 37-49.

Шагдарова Б.Б. Журналистика Бурятии в первой половине XX в. Улан-Удэ: Изд-во Бурятск. гос. ун-та, 2013.

Шестопалова Е.В. История становления и развития радиовещания в Иркутской области в 1920-1930-е гг.: дис. ... канд. ист. наук. Иркутск, 2008. 
Шуркина М.В. Периодизация истории Алтайского радиовещания (1925-1991 гг.) // $P R$ в изменяющемся мире: региональный аспект: сб. ст. / под ред. Т.Н. Голобородовой. Барнаул: Изд-во Алтайск. ун-та, 2002. С. 108-114.

Цуканова М.И. Первые десятилетия Воронежского радио: строительство станции, радиофикация области и роль радио в политическом просвещении воронежцев // Радио: начало истории. К 120-летию: сб. науч. ст. М.: Фак. журн. МГУ, 2017. С. 140-155. 